\title{
A Retrospective Cohort Study in patients over 55: Mechanical versus Biological valve prostheses
}

\author{
M Tarazi', K Sivabalah, N Mayooran, R Neagu, B Philip, MN Anjum, K Doddakula \\ From World Society of Cardiothoracic Surgeons 25th Anniversary Congress, Edinburgh \\ Edinburgh, UK. 19-22 September 2015
}

\section{Background/Introduction}

The choice between a mechanical valve and a biological valve is not always clear for patients requiring valve replacement surgery; age has been considered to be the determining factor in the decision making process. Previous guidelines have recommended the implantation of mechanical prostheses in patients under the age of 65 and biological prostheses in those over 65 .

\section{Aims/Objectives}

To investigate the life expectancy of patients over 55 who have had either a bioprosthetic or mechanical valve replacement and to establish if there is a significant difference in survival rates between these two valve groups. In addition, this research aims to investigate if factors such as hypertension, diabetes and a history smoking have an impact on the patients' survival.

\section{Method}

138 patient charts meeting the inclusion criteria, were identified using the percussionist database, and were used to extract the data relevant to the study. Data was analysed using SPSS.

\section{Results}

Of the 138 patients, $59.8 \%(\mathrm{n}=61)$ of the patients with biological valves and $58.3 \%(n=21)$ of the patients with mechanical survived between 5 to 10 years. The unpaired t-test and the chi-squared test performed showed that there was no statistically significant difference in the survival of patients who had biological valves and those who had mechanical valves.

\section{Discussion/Conclusion}

This study suggests that the type of valve prosthesis implanted does not affect the survival of the patients.

Published: 16 December 2015

doi:10.1186/1749-8090-10-S1-A345

Cite this article as: Tarazi et al:: A Retrospective Cohort Study in patients over 55: Mechanical versus Biological valve prostheses. Journal of Cardiothoracic Surgery 2015 10(Suppl 1):A345.
Submit your next manuscript to BioMed Central and take full advantage of:

- Convenient online submission

- Thorough peer review

- No space constraints or color figure charges

- Immediate publication on acceptance

- Inclusion in PubMed, CAS, Scopus and Google Scholar

- Research which is freely available for redistribution 